\title{
Justifying Territorial Claims in Classical and Hellenistic Greece: The Beginnings of International Law ${ }^{1}$
}

\author{
Angelos Chaniotis
}

\section{I. 'International law' or just a few good men with principles?}

The twenty-three Magnesian judges who were elected by their city in 112 BCE to resolve a territorial dispute between the Kretan poleis of Hierapytna and Itanos were not the first Greeks ever to confront such a task. In fact, it was not even the first time that their city had taken on the task of resolving this particular conflict; Hierapytna and Itanos had been fighting over a territory near the sanctuary of Zeus Diktaios from 145 onwards, and Magnesian judges had already dealt with this issue in $140 / 139$. But either because the judges of 112 were perhaps more conscientious than others, or because they wanted to be remembered for doing their job in the best possible way, they established a monument of their judicial work. This monument contains not just a written record of their verdict, but also a history of the conflict and, most important, the principles on which they based their decision. This document, of which two fragmentary copies survive in Magnesia on the Maiander and in Itanos, ${ }^{2}$ opens with a condemnation of conflicts and praise of peace and concord: just as circumstances often bring even the closest relatives into conflict, it is the duty of their friends to try their best to reconcile them (lines 14-17). This is the reason why the Magnesians willingly accepted the task of resolving the dispute.

When we were elected as judges, we immediately went up to the altar of Artemis Leukophryene and after the slaughter of a sacrificial animal we took an oath upon it, in the presence of the parties in the dispute from the two cities and the men who had come with them. And we took our seats in the sanctuary of Artemis Leukophryene and heard the conflicting parties to the end, providing them (for their orations) not only the daytime, but also most part of the night, taking upon us every laborious toil, so that neither of 


\section{The Law and the Courts in Ancient Greece}

the adversaries might have any disadvantage with regard to justice (lines 26-31).

After the representatives of Hierapytna and Itanos had presented their arguments, the judges made a final effort to reconcile them before taking a vote for the verdict; there is hardly any other Greek document which shows so clearly the preference of the Greeks for settlement (syllysis, dialysis) over judicial decision (dike). ${ }^{3}$ The enmity of the two Kretan cities was, however, stronger than the judges' good will. The Magnesians were left with no other choice than to give a verdict, which they justify in a long document of more than one hundred lines (the end is not preserved). In this document they narrate the story of the conflict in great detail, summarise the positions of the two parties, and quote older documents. The judges also give us the reasoning behind their decision as well as a theoretical statement about the arguments that can be used to support a claim of ownership (kyrieia) over land: ${ }^{4}$

Men have proprietary rights over land either because they have received the land themselves from their ancestors, or because they have bought it for money, or because they have won it by the spear, or because they have received it from someone of the mightier.

This formulation lists four modes of acquisition: inheritance, purchase, donation, and conquest - the first, second and fourth are undisputed, traditional principles of private law; only the third, the principle of conquest, was subject to controversy (cf. below $\$ 4.1$ ).

The subject of international arbitration has recently attracted much scholarly attention for two reasons: first, the ubiquity of territorial disputes in the ancient Greek world and, second, the numerous parallels the subject offers with the modern practice of international arbitration. But the legal and cultural significance of the reasons the Greek presented to justify territorial claims has generally been neglected. Recent studies of the subject have focussed more on collecting the evidence than on analysing the principles behind the decisions rendered by the judges involved in arbitration. ${ }^{5}$ One of the reasons for this neglect may be the widespread assumption that the Greeks had not developed a conception of 'international law'. ${ }^{6}$ In fact, modern scholars rarely use the term when discussing international relations in ancient Greece. ${ }^{7}$ On the contrary, scholars often regard the provisions and sanctions of treaties as the primary source for the legal rules to be applied in interstate relations. ${ }^{8}$ The arguments put forward to justify territorial claims are therefore not taken seriously, but regarded as mere propaganda. For instance, Ostwald dismisses appeals to the 'common laws of the Greeks' as 'pious platitudes'. ${ }^{9}$ The Greeks certainly lacked a written body of rules to be 


\section{Justifying Territorial Claims in Classical and Hellenistic Greece}

applied in disputes between poleis, that is, a set of statutes passed by a universally recognised legislative body and ratified by individual communities. They also lacked an agency that would enforce such rules. But it is still possible to have 'international law' as a set of:'rules, doctrines, and policy goals which exert a regulatory effect on international relations' without written legislation as long as these norms are consistently and regularly invoked and applied. In an important study of international law in Thucydides, G.E. Sheets has demonstrated that the unwritten nomoi of the Greeks were fully valid as a source of law and just as binding as treaties. ${ }^{10}$ Sheets shows that 'they could be expressed in the form of specific rules and doctrines, and they could be invoked as the principle basis for defining issues of disagreement and resolving those issues in an authoritative way'. Sheets ended his study by pointing to the need to compare the data found in Thucydides with the evidence found in other literary sources and in inscriptions.

The aim of this chapter is to develop the discussion begun by Sheets through a study of the justification of territorial claims in Classical and Hellenistic Greece. It focuses on the terminology used in documents concerning territorial disputes and attempts to demonstrate three main points. First, in the Classical and Hellenistic periods the Greek cities applied a well defined and differentiated legal vocabulary with regard to territorial claims. Second, the Greeks consistently used the same kinds of arguments to justify their claims to territory. The justifications presented by the parties in these conflicts exactly correspond to the four principles listed by the Magnesian judges at the end of the Hellenistic period (i.e. to precise legal principles). Third, these principles originated in the early Classical (or late Archaic period) and are closely connected with the principles applied for the resolution of property disputes among private citizens within the city.

\section{Phrasing distinctions: the terminology of ownership and possession in Greek 'international law'}

In a fundamental study, A. Kränzlein demonstrated that property law in the Greek poleis made a sharp distinction between ownership (Eigentum or lawful proprietary rights) and possession (Besitz). A close examination of the evidence - the epigraphic evidence in particular - reveals that the same distinction was consistently applied in decisions about disputes between poleis. It goes without saying that the relevant terminology is used consistently and with precision only in documents where differences in wording had legal consequences, not in texts that contain casual references to the possession of land. That is why it is necessary to focus here on documents about territorial claims.

Ownership is most commonly and unambiguously expressed by the 


\section{The Law and the Courts in Ancient Greece}

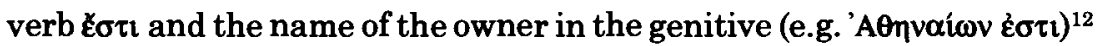

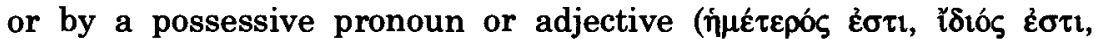

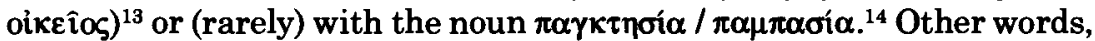

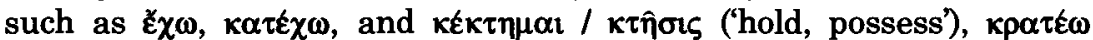

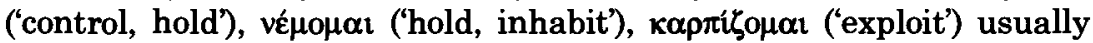
denote the possession of a territory without making any binding statement about its lawful ownership. ${ }^{15}$ Let us examine the use of the verb $\kappa \alpha \tau \varepsilon$ $\chi \omega$ ('occupy, possess'), one of the words most commonly used in such a context. In a document which concerns a border dispute between Amphissa and Delphoi (125 BCE) it is used to express the factual possession of land as opposed to its lawful ownership; ${ }^{16}$ the text refers to plots that had been given to the sanctuary of Apollon by the Roman senate; the proprietor was, therefore, the god (i.e. the sanctuary). These plots had been, however, occupied and exploited by some individuals (C lines 9f.: $\kappa \alpha \tau]$ ] $\chi 0 v \sigma$. Cf. C, line 28-D, line 4). The verb is used in exactly

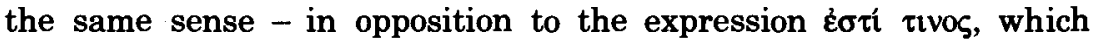
indicates lawful ownership - in the verdict of the Magnesian judges mentioned above $(\chi \dot{\omega} \rho \alpha v \ldots$..

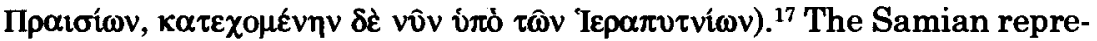
sentatives before the Rhodian court which had to resolve a territorial dispute between Samos and Priene (c. 197-190 BCE) ${ }^{18}$ used the verb

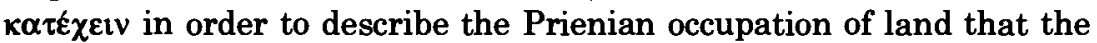
Samians regarded as their own lawful property (lines 111-13f.). In these cases, the context shows that this particular verb alludes to an unlawful occupation. ${ }^{19}$ But the same verb (as well as the verb $\varepsilon^{\chi} \chi \omega$ ) can be used in a neutral sense, without making any statement about the lawfulness of the possession, in texts which simply establish a terminus a quo as the basis for a verdict in a territorial dispute (cf. below pp. 193-4). In these cases the question is not who owned lawfully a territory, but who controlled it at a given time. This is how the verb $\kappa \alpha \tau \varepsilon \chi \omega \omega$ is used in a document concerning a conflict between Sparta and Messene (c. 138 $\mathrm{BCE}$ ) ${ }^{20}$ with regard to the question who occupied (not necessarily owned lawfully) the land in 146 BCE (lines 52-5; cf. lines 63-6). ${ }^{21}$ The verb

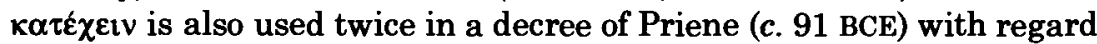
to saltworks, which were at that point exploited by the city (lines 114f.:

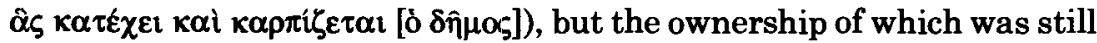
to be decided in the future (lines 116-18). ${ }^{22}$

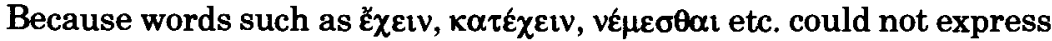
clearly the legal status of a territory, one often added an appropriate

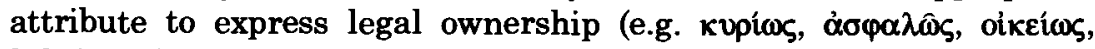

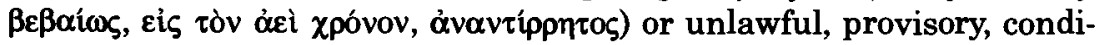

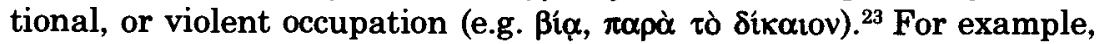
Eumenes I used a unique and almost redundant combination of attributes in a letter to Pitane (probably at the request of the people of Pitane) 


\section{Justifying Territorial Claims in Classical and Hellenistic Greece}

to make it absolutely clear that a piece of land was theirs and under their complete control: 'we grant the undisputable (anamphisbeteton) and acknowledged (homologoumenen) unlimited (pagktetiken) right of ownership (kyreian) for all time (eis aei chronon). ${ }^{24} \mathrm{~A}$ few characteristic texts demonstrate both these differences and the careful and differentiated use of a legal vocabulary.

An early and very instructive passage is provided by Xenophon in his Education of Kyros, in a passage in which Kyros addresses his victorious troops after the conquest of Babylon: 'None of you who possesses (echon) these things (i.e. the conquered land and houses) should think that he possesses (echein) property belonging to others (allotria); for there is an eternal law among the humans, that when a city is captured the conquerors own (einai ton helonton) both the bodies and the property of those who were in the city. ${ }^{25}$

Besides the reference to the right of conquest (see below \$4.1), what is significant in this passage is the distinction between possession (echein) and lawful ownership (estin tinos, allotria). Kyros' soldiers should not regard the possession of the conquered territory and goods

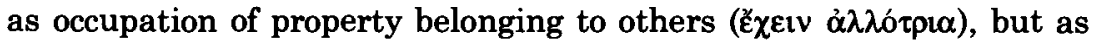

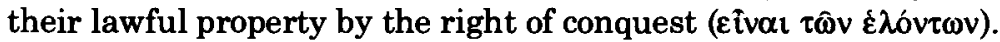

Another early, but unfortunately fragmentary, example of a clear contrast drawn between ownership and possession is found in a letter sent by envoys of Philippoi to their city, reporting a decision taken by Alexander the Great concerning a land dispute between their city and neighbouring Thracian tribes (330 BCE?) ${ }^{26}$ Different phrases are used to

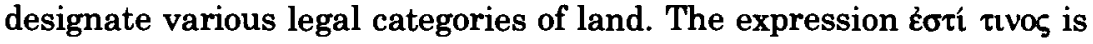
used only with regard to the marshes which were the lawful property of

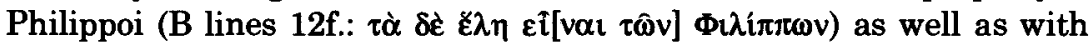
regard to land belonging to Alexander, but exploited by Philippoi under

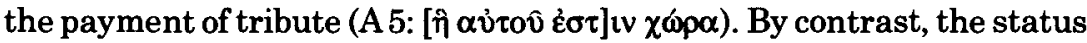
of land granted by Philip to the Thracians and to Philippoi was more ambiguous, and the author therefore avoids the clear and unequivocal

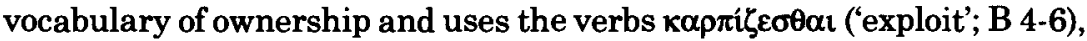

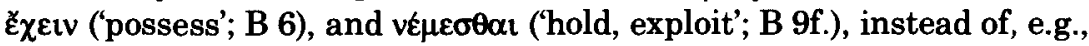

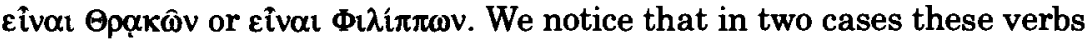
are followed by a reference to the exact conditions of possession ('just as Alexander decided about them' and 'just as Philip gave'); a similar reference may have stood in the third case as well (e.g. 'according to the same terms'). Most telling is the clause in B 9f.: the citizens of Philippoi had the right to hold and exploit a territory (nemesthai), under the conditions under which Philip, the land's lawful proprietor, had given it to Philippoi (kathaper edoke Philippos). The verb edoke is not used, here, to express transfer of ownership, but only the conditional transfer of property (cf. below p. 204). The conditions probably included the pay- 


\section{The Law and the Courts in Ancient Greece}

ment of tribute as in the case of another territory belonging to the Macedonian king (cf. A 4-6: prostelous[i phoron ...]). ${ }^{27}$

A conflict between Nagidos and Arsinoe provides another characteristic example of the careful distinction between possession and ownership. ${ }^{28}$ The Nagideis give their version of the controversy in a decree (lines 19-30):

When Aetos, son of Apollonios, a citizen of Aspendos and of our own city, became a general in Kilikia, he occupied a suitable site and founded a city by the name of Arsinoe, named after the king's mother. He settled new settlers in the place and he divided the land, which was ours (hemetera[n])), expelling the barbarians who had been inhabiting it (tous epinemomenous). And now his son Thraseas, who has been sent by the king as a general in Kilikia, shows great zeal in his efforts to make the city more glorious, and he has asked us to give up the public land (ten choran ten demosian, sc. our public land) to the inhabitants, so that they may possess it (ech[ein]) for all time, they and their descendants.

Although this text does not refer directly to a dispute, we know for sure that the decree of Nagidos was preceded by a long-lasting conflict between this city and the new foundation. This conflict is explicitly mentioned in a letter of Thraseas to Arsinoe (lines 4-6): 'Since now the Nagideis have followed our request and have marked out (the land) so that it may be yours (hymeteran einai) without any remaining controversy ...;' similarly, the decree of Nagidos forbids any further dispute on this matter (lines 40-5). Thus, the story can be plausibly reconstructed as follows: the Nagideis had lost control over the disputed land because of the raids of barbarians; they had not lost, however, its lawful ownership. They regarded this land as their property, even after Aetos had expelled the barbarians and had founded Arsinoe there (cf. below p. 199). For this reason they insisted upon the fact that they, the lawful owners - not Aetos or Thraseas - gave their land to Arsinoe. It was only after this rather theatrical, but legally necessary act that the land became the property of the Arsinoeis.

We see that the terminology of the documents that concern territorial conflicts in Classical and Hellenistic Greece reveals an awareness of important legal distinctions and the difference between possession and ownership as well as between conditional possession and violent and unlawful occupation. With these distinctions in mind, we can better understand the legal arguments advanced in many territorial disputes. 


\section{Justifying Territorial Claims in Classical and Hellenistic Greece}

\section{A few things judges want to know, a few things adversaries want to tell}

As we have seen, the Magnesian judges of 112 BCE recognised the existence of four ways of acquiring ownership: conquest, inheritance, purchase, and gift (see p. 186). Common sense tells us that these means of acquiring property are mutually exclusive. An argument such as 'I own this ring because I inherited it, and by the way I also bought it from my cousin' strikes us as very odd. If we expect from the Greek communities to have very clear, unambiguous views about the origin of their claim on a territory, we will be easily deceived in our expectations. As a result of wars, civil conflicts, foreign raids, or royal interventions, territories changed hands very often in the course of the turbulent history of the Greek world. These factors, combined with the various methods of proving ownership, gave rise to the complex disputes that confronted Greek arbitrators and judges, and, from the second century BCE onwards, the Roman Senate. To award ownership to one of the parties in a dispute, the judges had in theory to determine the historical moment that could be considered the foundation of a legitimate claim: is the decisive moment the initial possession of the territory, the last lawful transaction, or the moment of a major diplomatic event? These three ways of defining the question are mutually exclusive. 'One party is the lawful owner of the land because this party conquered it during the return of the Herakleidai, but also because they bought it forty years ago' also seems strange to us. Yet, in reality things are never as simple as that despite the very clear instructions given by the Roman Senate to Greek judges in international conflicts. As we are going to see, the use of multiple arguments is a very common phenomenon in Greek international arbitration.

A territorial dispute is the confrontation of two wishes: the wish of the adversary that holds a territory to retain possession and to have his ownership recognised and the wish of another party to take possession and gain ownership. The current occupant must explain how he came to possess the territory in a lawful manner; the adversary has to present his request as the termination of an unlawful state and as a return to an earlier, lawful situation. Things usually do not end here. If the plaintiff can provide some early evidence, then the defendant will try to prove either that the plaintiff's allegations are unfounded or that his ownership and possession dates to an even earlier period. Territorial claims thus inevitably turn to questions of origins and chronology. The conflict between Athens and Philip II over Amphipolis provides an interesting example. ${ }^{29}$ The corpus of the Demosthenic orations contains a letter, allegedly written by Philip, which presents the position of the Makedonian king; the letter is probably not authentic, but it still reflects 
the ideas of the time (and possibly the Makedonian arguments). Philip explains in this letter that three principles justify his claim: inheritance, conquest, and concession on the basis of a treaty:

For if (Amphipolis) belongs to those who have taken control of it originally, then who can say that I do not possess it justly, since Alexander, my ancestor, occupied that place first? ... But even if someone should dispute this and demands that it should belong to those who became its sovereign owners later, then I have this right as well. For I defeated after siege those who had expelled you and had been settled there by the Lakedaimonians, and captured the fort. Indeed, all of us inhabit our cities either because our ancestors have handed them over to us or because we have become their sovereign owners in war .... What other possession can be more secure than the possession (of Amphipolis), which was originally (ex arches) occupied by our ancestors, and became again ours in war, and thirdly was conceded (to us) by you, who have the habit of disputing even the cities which have nothing to do with you? ${ }^{30}$

Although the letter is probably not authentic, Philip's arguments find close parallels in the argument used by the Athenians in the same dispute as well as in arguments known from later documentary sources. The letter contains three different kinds of justification: original occupation, conquest in war, and recognition by treaty. A recently published Hellenistic inscription has a similar combination of justifications: King Eumenes II explains in a letter to Tyriaion that he was given Seleukid territory in Asia Minor after the peace of Apameia by its legitimate owners, the Romans, 'who have acquired control by war and by treaties'. ${ }^{31}$ In 'Philip's Letter' the grounds for the king's case are divided into 'original' (ex arches / protou) and 'later' (hysteron) claims. Aeschines (2.31-3) also separates earlier and later claims when he argues that Amphipolis belongs to the Athenians: Aeschines begins with the original occupation of the site (2.31: tes ex arches kteseos), then reminds the king that the Athenian rights were recognised by a peace treaty (2.32), ${ }^{32}$ and finally attempts to invalidate Philip's right of conquest (2.33; see below p. 198).

Aeschines' mention of the original status of Amphipolis is not a rhetorical device, but the sort of argument one expected an ambassador to make in such a situation. Arguments based on the initial occupation of territory in similar contexts in the epigraphic evidence show that we are dealing with a central issue in legal disputes over territories. The best documented case is the dispute between the Samians and the Prienians over Batinetis (cf. n. 18), which is described in a letter sent by King Lysimachos to the Samians: "The Prienians tried to demonstrate the initial (ex arches) possession of Batinetis with the help of historical 


\section{Justifying Territorial Claims in Classical and Hellenistic Greece}

works and other testimonies and documents' and 'they asked us to give them back the land on the basis of its initial possession'. ${ }^{33}$ Although the disputed territory had changed hands several times, the Prienians based their claim on the initial ownership of the land, using exactly the same expression as Aeschines. The Samians responded with a similar argument and pointed to the fact that they had inherited the territory from their forefathers. ${ }^{34}$ Several other inscriptions refer to requests to re-establish the 'original' (ex arches) status of the territory. ${ }^{35}$

The problems inherent in this principle become clear in the controversy over Amphipolis: when Philip II claimed that the area had belonged to the Makedonians in an early period (under king Alexander I), the Athenians replied by recounting their own legend: Theseus' son Akamas had received this land as a dowry. This argument in turn prompted the Makedonians to refer to still another legend: Amphipolis belonged originally to the Herakleidai. ${ }^{36}$ Some parties might go so far as to invent a historical narrative: the Rhodian judges who decided the conflict between Samos and Priene discovered that the history of Maiandrios cited by the Samians was not one of the author's authentic works.

The Romans were not particularly eager to be confronted with this type of argument, ${ }^{37}$ and established an entirely different principle: what judges should try to determine was not the original status of the territory, but who occupied it at a given moment of time ${ }^{38}$ This principle is not unknown in the earlier history of Greek interstate relations: as early as 380 , Isocrates recommended this principle as one of the ways to establish peace..$^{39}$ The earliest known dispute where this principle was applied is the conflict between Magnesia on the Maiander and Priene (c. 175-160 BCE). The Senate declared that the land should belong to whoever held it at the moment when Magnesia and Priene became allies of the Romans. ${ }^{40}$ Melitaia and Narthakion also appealed to the same principle in another territorial dispute (c. 140). ${ }^{41}$ The representatives of Melitaia claimed that the disputed public land and an abandoned fortress were their property when they concluded their treaty with Rome (lines 19-22); they also requested the Romans to confirm the validity of three earlier (favourable) verdicts. But the representatives of Narthakion claimed also that the disputed land belonged to them when they became amici (friends) of the Romans; they were also able to present a verdict that favoured them. The arguments are mutually exclusive, but there may be a plausible explanation: Melitaia and Narthakion must have become amici at different dates (Melitaia first, Narthakion later). The land must have changed hands exactly during the period in question, i.e. during the Second Makedonian War. ${ }^{42}$ The solution adopted by the Romans was to determine an earlier historical moment of decisive importance - the establishment of the Thessalian League by Flamininus - and to confirm the verdict given at that time 
(lines 63-5). Variants of the same principle were applied in other conflicts, in which the decisive terminus a quo was the first involvement of the Romans with the issue in question. ${ }^{43}$ The Senate occasionally deviated from this rule, as in the case of the conflict between Priene and Samos (135 BCE) when the Senate decided not to confirm a decision by Manlius Vulso in 188, but an earlier verdict given by Rhodian judges. ${ }^{44}$

No matter how the issue that the judges had to resolve was formulated, the contestants would not only present evidence relevant to this issue, but they would attempt to influence the judges with an impressive variety of arguments. These arguments are often summarised by the judges in their verdicts, and there are a few examples of testimony given by witnesses. ${ }^{45}$ One of the questions that seem to have been relevant for the verdict was whether or not the lawful owner exercised the rights of ownership. ${ }^{46}$ Two of the foreign witnesses presented by Kondaia testified that the city was in fact exploiting the disputed land by extracting a transit toll (line 17f:: paragogion), cultivating it (line 27-8.: georgountas ... kai nemomenous), and having a keletra (line 35f; the meaning of the word keletra is not clear). Other advocates presented evidence for transactions that had taken place, in or with regard to, the disputed territory without giving rise to protests from their adversary; this could be taken as a tacit recognition of territorial claims. ${ }^{47}$ The duration of the occupation and exploitation of the disputed territory is very often legally irrelevant, but it was still a point that the parties liked to make to the judges. This is why we often find references to the ancestral rights or to the possession of land for many generations. ${ }^{48}$ When Lysimachos almost apologises to the Samians for listening to the arguments of their adversaries from Priene (cf. pp. 192-3), it is because he was not aware that the Samians had held the disputed territory for so long: 'if we had known that you had had this land in possession (echein) and use (nemein) for so many years, we should never have undertaken to hear the case. ${ }^{49}$

Of course, the most important argument in a territorial conflict would always be the proof that the territory in question had been acquired by a community in one of the four ways specified by the Magnesian judges (see p. 186) and had henceforth remained in its possession. It is these four legitimate means of acquisition of territory that we will now examine, focusing in particular on some factors that could limit the application of these principles.

\section{Acquisition of territory in international law}

\subsection{Conquest}

When the Magnesian judges explained that one of the means by which communities acquire land is victory in war (dorati kratesantes), this 


\section{Justifying Territorial Claims in Classical and Hellenistic Greece}

would not have come as a surprise to the Kretans who heard their verdict. The Hellenistic period had seen more wars of conquest on Krete than any earlier period in the history of the island. ${ }^{50}$ Nor would most of the Greeks, perhaps with the exception of some philosophers, have been shocked by such a statement. The national legends of every Greek community - at least those who did not claim to be autochthonous contained a successful act of violence that had established its ownership of its territory.

But there is no need to look to the myths for the right of war. According to Aristotle the art of war is one of the skills by which men acquire the ownership of goods. ${ }^{51}$ This practice was recognised as customary law (nomos). An important passage in Thucydides is quite revealing. After their defeat at Delion (424 BCE) the Athenian troops occupied the sanctuary of Apollon, which was in Boiotian territory. When the Thebans sent a herald to protest against their action, the Athenians responded as follows: The Greeks have a law (nomos) that whoever has under his power (kratos) a piece of land, whether big or small, also owns (gignesthai tinos) the sanctuaries, managing them in the same manner as before to the best of his ability. For the Boiotians, as well as most other men, have used violence to expel another group of people and now hold (nemontai) their land, having as their own (oikeia kektesthai) those sanctuaries, which belonged to others (allotriois) when they first came upon them. ${ }^{52}$ The argument presented by the Athenians (as presented by Thucydides) deserves comment. The Athenians observe that most of the other Greeks have seized land that used to belong to others, implicitly drawing attention to their own autochthony. After the violent expulsion of the previous owners (bia nemontai), the conquerors acquired the land (and its sanctuaries) as their own (oikeia kektesthai). The foreign object of conquest had become their property, on which they exercised control (cf. kratos). This principle was in accord with the customary law of the Greeks.

The acquisition of ownership through the right of conquest is also found as a principle of international law in Xenophon's Education of Kyros (see note 25): 'there is an eternal law (nomos) among the humans, that when a city is captured the conquerors own (einai ton helonton) both the persons and the property (chremata) of those who were in the city.' Like Thucydides, Xenophon presents the right of conquest as a law; since the context is a Persian one, he does not speak of a Greek law, but of a law that applies to all human beings. In this respect, the passage reminds us of the formulation used by the Magnesian judges ([an]thropoi tas kata ton topon echousi kyrieias). The more general formulation was necessary in this case because the verdict was requested not just by two Greek communities, but by the Roman Senate. We find the same idea in the letter attributed to Philip concerning his claims on Amphipo- 


\section{The Law and the Courts in Ancient Greece}

lis (cf. p. 192): 'all of us inhabit our cities either because our ancestors have handed them over to us or because we have acquired control of them (kyrioi) in war.'

There is more evidence for the right established by conquest and war in the Hellenistic period, but it does not alter the picture described in the earlier sources. ${ }^{53}$ One of the most interesting cases is the arbitration of Pergamon in a dispute between Mytilene and Pitane. ${ }^{54}$ The Pitanians had bought the disputed land from Antiochos I, the successor of Seleukos I, who in his turn had acquired it after the victory over Lysimachos (line 132: [...machei epi] kratesantos). The many documents quoted in the verdict of the Pergamene arbitrators (lines 133-44) leave no doubt that the question they had asked was whether this transaction was lawful or not (cf. lines 149f.), i.e. whether Pitane had bought the land from its lawful owner (cf. below p. 203). Although this is not stated explicitly in the fragmentary inscription, it seems certain that the question was whether Seleukos' victory at Kouropedion made him and his successor lawful owners of the land and therefore gave them the right to sell it..$^{55}$ This right was recognised by the Pergamene judges because it had been confirmed by Philetairos and Eumenes I.

The same question arose in the negotiations between Eumenes II and Tyriaion sometime after $186 .{ }^{56}$ The inhabitants of Tyriaion seem to have received the status of a polis under the Seleukids, a grant that Eumenes regarded as invalid because the Seleukids were not the lawful owners of the territory (lines 22-3: hypo ton me kyrieuonton). In a dramatic gesture, he made Tyriaion a polis, but also stressed that he was the one who had the right to make the grant since he was the lawful owner of the territory (lines 20-1: ektemenou kyr[i]os). The claim was founded on the fact that he had received it from the Romans, who had won (epikratesanton) it both in war (polemoi) and through treaties (synthekais) (lines 21-2). . $^{5}$

The principle that the violent conquest of foreign land establishes a legitimate ownership is therefore neither a literary fiction nor an arbitrary claim made by the Magnesian judges. One may find an analogous idea in private law, which also recognised violent forms of acquisition of property (war booty, booty of pillage). ${ }^{57}$ The origins of this idea cannot be determined with certainty, but it is certainly older than the Sophistic idea that might makes right. The reason why the principle occurs in both private and international law is possibly not mutual influence, but common origins, which are probably connected with idea that success in a violent activity (war, piracy, raid) cannot be achieved without the support of the gods and may be viewed as the punishment of the defeated party. The most instructive example of a defeat in war seen as punishment for unjust behaviour is that of Athens' defeat in the Peloponnesian War. As Xenophon explains (Hell. 2.2.10), the Athenians 


\section{Justifying Territorial Claims in Classical and Hellenistic Greece}

believed they suffered not for the punishment (timoroumenoi) they inflicted on others, but for the injustices they committed through their own arrogance (dia hybrin edikoun).

Divine support for acts of piracy is implicitly recognised in the custom of dedicating a tithe of the booty to the gods - a thanksgiving dedication corresponding to the idea of $d o u t d e s .{ }^{58}$ The earliest piece of evidence for this idea is the archaic inscription of Aiakes of Samos (c. 500) who dedicated to Hera part of the booty won during sea raids. ${ }^{59}$ An interesting appeal to this principle is found in the arguments made by the Samians in a conflict with Priene over the fort Karion and the region called Dryoussa. ${ }^{60}$ Their claim on these areas was based on the right of conquest, after the destruction of the Karian city of Melie and the division of its land, and it was confirmed through the 'verdict of their victory (nikas krisin)' in a battle against the Prienians (lines 105-6). ${ }^{61}$

This principle does not seem, however, to have been unanimously accepted without qualification. A careful reading of two passages of Isocrates (who makes the same distinction between possession and ownership we have already encountered) shows that the orator did not think that conquest always establishes a legitimate claim. In his Panathenaic Oration he implies that the conquest of the Peloponnese by the Dorians was illegitimate: 'They divided the cities and the territories which they took from their lawful owners (tous dikaios kektemenous). ${ }^{\prime} 2$ In his oration On the Peace (17) he refers to powers that possess (katechonton) the cities of others by violence (biai); this phrase gives one the impression that the defeated party remains the legitimate owner. Yet in other places Isocrates regards violent conquest as a legitimate means of acquiring ownership. ${ }^{63}$ One might explain these apparent contradictions in Isocrates' views as resulting from the different contexts in which he expresses them or to his moralising tendencies. One can trace the same moralising ideas in Aristotle's treatment of slavery, and particularly enslavement in war. Aristotle (Pol. 1255a11-25) reports the variety of opinions about the subject, then says that some thinkers regard slavery as a result of war as just. Then follows an objection to this view: a war may be unjust. ${ }^{64}$

But there is probably more in Isocrates' views than just philosophical preferences. The different attitudes were noticed by $\mathbf{E}$. Bickermann and J. Sykoutris, who have emphasised the importance of the motivation for the violence that leads to possession. Conquest in general does not create the right of ownership, but only violence undertaken as a result of provocation or as vengeance for injustice. ${ }^{65}$ Although the Magnesian judges, Thucydides or Xenophon did not make such a distinction, the legitimacy of the act of violence appears to have played a key role. The very fact that the Greeks, both in legend and in historical documents, tried to present just causes is clearly related to this principle. ${ }^{66}$ One can 


\section{The Law and the Courts in Ancient Greece}

find further evidence for the principle in Demosthenes' Against Ktesiphon, where the orator denounces Philip's aggression: 'he takes away cities that do not belong to him; he has even won by the spear some of the cities of the Athenians, without having first suffered injustice at the hands of the Athenian people. ${ }^{67}$ The orator is not criticising conquest in general, but unjustified, unprovoked conquest. The importance of this distinction can be seen in a document of an entirely different nature, a curse tablet deposited in a grave in Oropos. An anonymous man curses a series of persons and places all his hopes in the gods of the underworld who will respond to his request and punish his opponents precisely because he had been wronged without having wronged them first. ${ }^{68}$ This idea persisted until the late Hellenistic period. When envoys of Hierapytna appeared before the Roman Senate to defend their claims over a disputed territory, they made sure to mention the fact that they had not attacked or wronged their adversary, Itanos. ${ }^{69}$

The specific circumstances of the conquest might also affect the legitimacy of ownership through victory in war. The case of Amphipolis is revealing. Aeschines claimed that a treaty that Amyntas had sworn awarded the city to the Athenians; however, the resistance of the Amphipolitans prevented the Athenians from taking control of the city. In 360 Perdikkas, Philip's brother, conquered Amphipolis, but after his death (359) Philip relinquished control over the city to avoid challenging Athenian claims. But the city managed to retain its autonomy until Philip reconquered it in 357. We have already examined Philip's claims to the city. Aeschines replied to Philip's claims with an argument that was more than just a technicality:

If you argue that you reasonably possess Amphipolis by having taken it in war, if you had won the city with spear fighting against us, then you would be the sovereign owner (kyrios echeis), having acquired it according to the law of war. But if you have taken the city belonging to Athenians from the Amphipolitans, then you do not possess their property, but the territory of the Athenians. ${ }^{70}$

Aeschines did not challenge Philip's right of conquest, which he admits was consistent with 'the law of war'; he does not even ask whether Philip had fought a just war against Amphipolis or not. What undermined Philip's claim on the city was the fact that Philip had taken Amphipolis not from its lawful owners (the Athenians), but from the Amphipolitans. That this was not a technicality or a rhetorical device of Aeschines can be inferred from a similar situation with regard to Philip's claims on Halonnesos, ${ }^{71}$ which had previously belonged to the Athenians. When Philip took the island defeating the pirates who had occupied it, this did not affect the Athenian claim on the island. For this reason Demos- 
thenes insisted that Philip should not 'give', but 'return' the island to the Athenians (7.5; 12.14; cf. Aeschin. 3.83). Giving is the right of the lawful owner, and Philip was not the rightful owner. This play on words, which the comic poets ridiculed,$^{72}$ had important legal implications. Isocrates uses the same type of argument to legitimise the Dorian occupation of Messene. Messene was deposited for safekeeping (parakatatheke) in the hands of Nestor but did not belong to him; the legitimate owners were the Herakleidai. ${ }^{73}$

The documentary sources contain more examples of this kind of argument. We have already seen (p. 190) that Nagidos regarded a territory as its lawful property although it had been occupied by barbarians. When a Ptolemaic general expelled these barbarians, occupied the land, and founded a new city there, the Nagideis still regarded this land as their own public land (lines 22-3, 26). From their point of view, they had never lost ownership, despite these changes, presumably because they had not lost this land after a defeat in a just war. The dispute between Samos and Priene over a strip of land north of Mykale called Batinetis is very similar (see n. 18). When king Lysimachos was asked to arbitrate in $283 / 2$, the disputed territory was in the possession of the Samians, but the Prienians claimed that it had orginally belonged to them. They temporarily lost it in the seventh century BCE, during the Kimmerian invasion under Lygdamis, but after a period of three years the land was 'returned' to them. It is crucial to observe here the emphasis the Prienians place on the word 'return' (apodidonai). ${ }^{74}$ According to the Prienians, there were no Samian citizens there at that point, except for a few Samian lessees of Prienian land; the Samians brought the land under their control later. The Samians had a different story to tell, but they relied on the same principle: the violent, temporary occupation by the Kimmerians had not terminated their ownership. They admitted that they had left this land after the Kimmerian invasion, but the interruption of their control over the land did not invalidate their claim. Unfortunately the stone breaks off at this point so we do not know the rest of their arguments. In the missing portion of the inscription the Samians may have claimed either that they returned to the land after the Kimmerians had left or that they remained its lawful owners despite the grant of this territory by Lygdamis to the Prienians alone. ${ }^{75}$

Not every military victory established legal claims. The reasons for the war (unprovoked, unjust) and the actual circumstances of the conquest might limit the application of this principle. Some vague references to an unjust or unlawful occupation may in fact be connected with such arguments. ${ }^{76}$ 


\section{The Law and the Courts in Ancient Greece}

\subsection{Inheritance}

The acquisition of land by inheritance is an argument that we have already seen listed next to conquest in the verdict of the Magnesian judges. Inheritance is also found in the letter allegedly written by Philip with regard to his claims on Amphipohs: 'All of us inhabit our cities either because our ancestors have handed them over to us or because we have become their sovereign owners in war' (cf. p. 192). Unlike the right of conquest, inheritance is a well known part of property law and seems to require no comment. ${ }^{77}$ But the right of inheritance in international disputes has some important ideological implications, in particular in regard to the means by which the various parties prove they have acquired property by inheritance, i.e. the use of history as an argument.

Ancestral rights play a key role in the earliest attested references to territorial conflicts. The cult of the ancestors is directly connected with this phenomenon, since the presence of their graves in a disputed territory was often used to prove long-standing claims to land. One of the earliest traditions about interstate arbitration, a decision of king Pausanias in a conflict between Athens and Delos, reveals how much weight this argument might carry. Pausanias is reported to have assigned the island to the Athenians because the Delians were unable to point to any graves on the island where their ancestors were buried. ${ }^{78}$ Of course, this story may be just a joke: how could the Delians possibly identify the graves of their ancestors, since all graves had to be removed from the island twice, in the sixth and again in the fifth century BCE? Yet, we find a similar tradition in connection with the Athenian claims to Salamis. Solon is said to have demonstrated that the burials on Salamis corresponded to the Athenian and not the Megarian customs the first case of a state exploiting 'archaeological' finds for political purposes. ${ }^{79}$

There was a major difference between private property law and the practice in international arbitration. In private property law only direct inheritance establishes proprietary rights, whereas in Greek diplomatic history the appeal to ancestral rights appears only when one of the parties could not establish a continuous and unbroken line of inheritance. We have already seen that a community could raise a claim that was based on the rights of the ancestors even if these rights had not been exercised for a long period of time. ${ }^{80}$ As a result, historical traditions became one of the most important means of justifying claims to a territory. The trouble was that if one side presented a historical argument, the other side might retort by presenting another historical argument that contradicted their opponents' argument. Historical arguments figured prominently in the conflict between Athens and Philip II of Makedonia over Amphipolis. Both parties had legal arguments on 


\section{Justifying Territorial Claims in Classical and Hellenistic Greece}

their side. The Athenians could provide documents (various peace-treaties and letters of Philip); Philip, on the other hand, appealed to the generally accepted right of conquest. And yet, although both parties in the conflict had legal arguments, they buttressed their claims with historical arguments. In this context Aeschines uses the word (2.31); it was appropriate to remind Philip of the myth that Akamas, Theseus' son, had acquired this territory in legendary times as the dowry of his wife. Not to be outdone, Philip hired the historian Antipater of Magnesia, who provided the necessary mythological and historical arguments: Amphipolis belonged originally to the Herakleidai, Philip's ancestors. After the Persian Wars King Alexandros I had ruled over this land, as a golden statue in Delphoi demonstrated - again an archaeological argument. ${ }^{81}$ The object of the dispute was shifted by both parties to the first occupation of the land (ex arches ktesis - see above p. 192) ${ }^{82}$

In such cases the legal issue might become the object of historical research. Historiographical works were used, old poems recited, oracles and documents quoted and forged.$^{83}$ When rendering their decision, the judges often had to choose which historical tradition they regarded as the most trustworthy. A better known and more characteristic case is provided by the latest stage in the conflict between Priene and Samos over territories on the coast of Asia Minor, the fortress Karion and neighbouring Dryoussa (c. 197-190 BCE). ${ }^{84}$ The Samians (who lost the case in this bout) cited the work of Maiandrios, a Milesian historian of the fourth century, who stated the disputed territory belonged to Samos since the end of the 'Meliac War' in the eighth century. They also cited the works of the Samian historians Euagon, Ouliades, Olympichos, and Douris. On their side the Prienians had the testimony of the historians Theopompos of Chios, Kreophylos, and Eualkes of Samos. These historical works supplemented many documents brought forward by the parties. What is even more interesting is the way the Rhodian judges, who had to decide this case, treated the evidence. They compared the different versions of the story of the Meliac War and found out that only the 'Histories' attributed to Maiandrios of Miletos reported that the Samians were allotted the disputed areas of Karion and Dryoussa after the war. On the other hand, most of the other historians disagreed with this version and argued that this work was not a genuine work of Maiandrios. Not only did the Rhodian judges work like modern historians, critically examining the historiographical material presented to them, but they also founded their verdict on a historical tradition.

The case of Amphipolis reveals the problems involved in such historical arguments. When Philip dated the initial occupation of this area under the rule of king Alexandros I, the Athenians responded with an even earlier claim. Philip then pointed to an even earlier legend. Given the Greeks' inventiveness with regard to myths, this competition could 


\section{The Law and the Courts in Ancient Greece}

have easily been continued ad infinitum. ${ }^{85}$ It is not easy to choose among historical accounts, and the oldest claims are not necessarily the most reliable. This was obvious to the contemporary Greeks. It is interesting, e.g., to observe how Aeschines in his summary of the speech that he gave to Philip skips the historical arguments to come to the recent, legal foundations of the Athenian claims (2.31). This combination of historical and legal arguments underlines even more the prominent position of the historical traditions in the justification of territorial claims. Even when a city had a legal argument, it was nevertheless expected to add arguments from history.

The tantalising questions are of course, why such historical arguments were indispensable and how effective they might really have been. These two questions cannot be discussed independently. A first important factor should be seen in the nature of Greek international arbitration; the decisions were not taken by 'professional' jurists, but by elected judges who represented their city's assembly. The advocates had to deal with a very heterogeneous group of people. Different arguments would appeal to different individuals; in a procedure in which orality played a major part, arguments closely connected with religion and morality had good chances to prevail. Another, perhaps more important, reason for the use of historical arguments, should be seen in the fact that for the Greeks, in general - in constitutional history and in the legal relations between states - the present acquired to a large extent its legitimacy from the past. We can best see the power of historical arguments in the cases in which they were legally irrelevant. In the case of the conflict between Hierapytna and Itanos, the Magnesian judges in 140 and 112 BCE had to answer a very clear question: who possessed the disputed territory immediately before the beginning of a war in 140 ? This did not prevent the representatives of both adversaries from referring to ancestral claims (see p. 193). Did this influence the judges? Naturally, it is impossible to tell, but I do not think it is a coincidence that the judges in both verdicts do not simply state that the Itanians owned the land when the war started, but go on to underline the fact that this land was their ancestral territory ([progo]nikas $)^{86}$ and that they were its original owners (apo arches). ${ }^{87}$

It is this effectiveness of historical arguments that makes them appear almost as a ritual play, an indispensable part of diplomatic contacts. Aesop's fable about the wolf and the lamb can be seen as a comment of a keen-sighted observer of the use of historical arguments in territorial conflicts:

Once a wolf saw a lamb that had strayed from the flock, but instead of rushing upon him to seize him by force, he tried to find a plausible complaint by which to justify his hostility. 'Last year, 


\section{Justifying Territorial Claims in Classical and Hellenistic Greece}

small though you were, you slandered me.' 'How could I last year? It's not a year since I was born. 'Well, then, aren't you cropping this field, which is mine?' 'No, for I've not yet eaten any grass nor have I begun to graze.' 'And haven't you drunk from the fountain that is mine to drink from?' 'No, even yet my mother's breast provides my nourishment.' Thereupon the wolf seized the lamb and while eating him remarked: 'You're not going to rob the wolf of his dinner even though you find it easy to refute all my charges.'

\subsection{Sale}

The acquisition of land by a community through purchase is not attested very often, but it is a recognised principle of interstate relations. The earliest instance attested in literary sources is the effort of the Phokaians to buy the island Oinousai from the Chians (Hdt. 1.165.1); the Eleians bought the territory of Epeion for 30 talents in the fifth century BCE (Xen. Hell. 3.2.30f.). In the Hellenistic period, Attalos I purchased Aigina from the Aitolians in 210,88 Rhodos bought Kaunos from the Ptolemies for 200 talents around 197, ${ }^{89}$ and Pitane claimed that it had purchased a disputed territory from King Antiochos I (see p. 196). The purchase of land alone is, of course, not a sufficient basis for claiming ownership: the seller must be the lawful owner of the sold object.9 We have already seen that this was the question which the Pergamene judges had to decide in the case of the land which Pitane had bought from Antiochos (see p. 196). Was Antiochos the lawful owner of the land his father had won by the spear or not? A nice example is provided by the inscription which concern the restitution to the sanctuary of Apollon at Delphoi of plots of sacred land which were unlawfully occupied (katechein) by some individuals. ${ }^{91}$ The last section of this document lists these unlawful occupants who had to return the land and demolish any buildings that might have been built on it (C 28-D 4). One of these occupants was Hagion who claimed (possibly truly) that he had bought this particular plot (D 3f.: egorakenai). Since he had to give the land back, he must have purchased it from an earlier unlawful occupant.

The conditions of sale could also be legally relevant. In $400 \mathrm{BCE}$ the Spartans took from the Eleians the territory of the Epeians, which they had bought from 'those who possessed (echonton) the city then'. Obviously, the Eleians appealed to a transaction which the Spartans claimed was illegal. They argued that a purchase that had taken place under pressure (bia priamenous) was not in any way more just than violent deprivation (bia aphelomenous).$^{92}$ Xenophon's report is very brief, but it seems plausible that the Spartans did not reject the right of conquest in general, but only the violent seizure of property under certain conditions such as in an unjust war. The phrase 'those who possessed the city then' 


\section{The Law and the Courts in Ancient Greece}

is rather suspicious. In view of the parallels mentioned above, one is tempted to think that the Eleians bought Epeion not from its lawful owners, but from some temporary intruders. Unfortunately we have no further information on this matter.

\subsection{Donation}

Cases of donation of a territory are hard to find earlier than the Hellenistic period. The case of Epidamnos which was handed over (paredosan) by its inhabitants to Korinthos just before the beginning of the Peloponnesian War, is a particular case, involving the relations between colony and mother city. ${ }^{93}$ Other references to donation (dosis) are connected to legends, such as the gift of Amphipolis to Akamas as a dowry (Aeschin. 2.31) or the donation of Lakedaimon and Messene to the Spartans (Isocrates Archid. 18 and 24). Another particular case of (not entirely voluntary) donation has already been discussed above ( $p$. $190)$. Arsinoe gave ( $\delta i \delta \omega \mu \mathrm{t}$ ) a disputed territory (in fact held by Nagidos) to Nagidos, following a request by the strategos of Kilikia; the grant of the land meant a full and permanent transfer of lawful ownership; the conditions were regulated not by a treaty, but by a decree of Arsinoe (late third century BCE) ${ }^{94}$ The gift of territory is regarded as one of the possible (but in this particular case explicitly forbidden) means of acquisition in a peace treaty between Magnesia on the Maiander and Miletos (c. 185-180 BCE) ${ }^{95}$ One-sided grants of territory are of course very common in the period of the Roman expansion, such as the famous (and controversial) donation of Lykia to Rhodos 'as a gift' (en dorea). ${ }^{96}$

In the documentary evidence the verb $\delta i \delta \omega \mu$ is used to designate the transfer of property as a gift or testamentary donation. ${ }^{97}$ However, it often designates a conditional transfer of possession, and not the unconditional change of ownership. ${ }^{98}$ The most important piece of evidence is a treaty between the Kretan city of Praisos and the dependent community of Stalai. ${ }^{99}$ The terms of the transaction are as follows: "The Praisians gave to the Stalitai the territory and the city and the islands, which they possess (zxovor) now, ${ }^{100}$ and one half of the harbour revenues and of the tithe imposed on the fishing of purple and of fish, exactly as before. They have given all these for all time, securely and sovereignly, to them and to their descendants. ${ }^{101}$ According to the more probable interpretation of this ambiguous passage, the Praisians had conquered Stalai and became the owners of the land, the city, and the islands. Initially, the Praisians kept the city and the land, conceding to the Stalitai only the islands. With this treaty the Praisians, as the lawful proprietors, give to the Stalitai the territory and the city. The new arrangement allowed the Stalitai unlimited possession, but did not transfer ownership. The transfer was a conditional donation (cf. epi 
toisde edokan), which could be annulled if the Stalitai did not abide by the conditions of the donation (i.e., the payment of tribute and the offering of other services). The payment of tribute, in particular, shows that the Praisians remained the owners of the land they donated. ${ }^{102}$

\section{The 'common custom of the Greeks': beyond literary fiction and closer to international law}

With the exception of the theoretical statement of the Magnesian judges (see p. 186) the documentary sources give us no direct and explicit information about generally recognised principles, and we do not find references to legal precedents. ${ }^{103}$ This does not mean that such principles did not exist. The declaration made by judges that they have given or would give a verdict in a just or the most just way presupposes some basic conceptions of law and justice. ${ }^{104}$ That these conceptions are not defined and were not written down does not necessarily mean that they were vague. On the contrary, it could easily mean that they were generally known and accepted.

As this study has shown, both the literary and the epigraphic evidence from the fifth to the second century reveal a high degree of uniformity both with regard to the vocabulary of proprietary rights, ownership, possession, and occupation and with regard to the arguments presented by the adversaries in order to justify their territorial claims. The use of terms in the literary sources corresponds closely to the usage in the inscriptions. Despite the existence of a very rich vocabulary that expresses various degrees of possession (p. 188), we have observed its careful, subtle, and differentiated use not only within the same document, but also in many documents from different areas and periods of time. Finally, we have seen that the four means of acquisition of property mentioned by the Magnesian judges were often applied in territorial disputes. Their validity was not unlimited; the exact circumstances were often legally relevant. These general rules and their limitations are attested in texts from different periods and areas, both in literary sources and in inscriptions. For this reason it seems plausible to assume that despite the absence of any theoretical treatise or written principles, the Greeks had from the Classical period (at the latest) onwards a clear conception of this aspect of their interstate relations and a fixed set of principles applicable in interstate disputes about land. These principles can and should be regarded as 'international law' because of the remarkably high degree of consistency in their application and in the use of the relevant terminology - a consistency that is even more remarkable considering the absence of a written body of rules. We know about conflicts that lasted for decades or even centuries, because one of the parties in the conflict refused to 


\section{The Law and the Courts in Ancient Greece}

accept the verdict rendered by the arbitrators or judges. In such cases, however, the parties did not challenge the validity of these customary principles, but the way they were applied in a particular case, the historicity of the claims, the veracity of their adversaries' statements, or the authenticity of documents. ${ }^{105}$ On the other hand, I do not know of a single case where the customary principles were not applied (explicitly or implicitly) or had been rejected and criticised.

The question when and how these principles came into being is not easy to answer. Most of them are closely related to and probably originate in civic property law (especially the right of inheritance, which is attested earlier than donation and purchase). In several cases one can observe a similarity between the arguments used in the courts of individual poleis and those found in interstate disputes. ${ }^{106}$ Another influence seems to come from the practice of warfare, for which the Greeks had generally recognised rules ${ }^{107}$ and which is naturally connected with territorial disputes. Two (not necessarily trustworthy) references to early interstate agreements mention precise rules about permissible conduct in war: the use of weapons striking from afar in the Lelantine War (first half of the seventh century?) ${ }^{108}$ and the prohibition of cutting a city of the Delphic Amphictyony off from water supplies in the Amphictyonic Oath (allegedly early sixth century). ${ }^{109}$ A common element in both traditions is the role of a sanctuary (that of Artemis in Amarynthos and the Delphic sanctuary) and the participation of more than two communities in the agreement. Even if the historicity of these traditions is questionable, it is conceivable that local amphictyonies may have contributed to the development of generally accepted principles of the proper conduct in war (e.g. the respect toward the sacred truce of Panhellenic competitions). It may not be merely coincidental that the references to 'common laws of the Greeks' concern the right of conquest, sacred truces, and the treatment of prisoners. ${ }^{110}$ Besides the part played by sanctuaries as meeting places in Archaic Greece and as places where documents concerning interstate relations (treaties, arbitrations, marking out boundaries) were made public, another important factor for the wide diffusion of certain rules and legal conceptions was the greater frequency of diplomatic contacts from the late sixth century onwards, and the resulting increase in bilateral and multilateral treaties, the use of already existing models for drawing up legal documents and the exchange of written documents. ${ }^{111}$

Of course, in international arbitration the judges did not take decisions 'according to the laws' (kata tous nomous) but 'in accordance with what is just' (see n. 104). But neither this nor the absence of a written and ratified set of statutes are reasons to deny the existence of international law in ancient Greece. It is more important to observe that an undisputed set of principles was consistently applied in international 


\section{Justifying Territorial Claims in Classical and Hellenistic Greece}

arbitration. The conclusions of this study therefore converge with those about unwritten laws and the laws of the polis reached independently by Edward Harris in his chapter on Sophocles' Antigone. Apart from international bodies like the Delphic Amphictyony, the Greeks did not have an authority that oversaw the uniform application of these rules. Yet the gods, so solemnly invoked in the oaths of the parties to the dispute and the judges, did represent the ultimate authority that would punish lawless and unjust behaviour. ${ }^{112}$ The intellectuals certainly made their jokes about the belief that the gods punish wrongdoers ${ }^{113}$ or associated the creation of the faith in gods with the hope of a more effective implementation of justice. ${ }^{114}$ Yet this attitude never uprooted the idea that the gods did not neglect crime and injustice. If an evil man managed to escape punishment during his lifetime, the belief that divine punishment awaited him after death or would strike his descendants afforded some consolation to the just even if it did not deter wrongdoers. ${ }^{115}$ As late as the early third century BCE the polis of Dodona asked the local oracle whether the god had sent bad weather as a result of some man's impurity ( $S E G$ 19.427). And two hundred years before many Athenians thought their defeat in the Peloponnesian War was a divine punishment (Xen. Hell. 2.2.10). The fear of the gods was not necessarily or always less effective than the fear of United Nations sanctions in modern international law.

\section{Notes}

1. I would like to express my warm thanks to Edward Harris and Lene Rubinstein for their extremely helpful comments on an earlier draft of this chapter. Their invitation to contribute to this volume has given me the opportunity to reshape a paper written in 1983. I have very much profited from Fritz Gschnitzer's criticism of the original version. I should also like to thank Dr James Cowey and Edward Harris for correcting my English.

2. I.Cret. III iv 9. For a recent edition of the entire document and bibliography see Ager (1996) no. 158 II. For further bibliography see Chaniotis (1996a) 307-11, no. 49 and 333-7, no. 57; Guizzi (1997); Boffo (2001) 37.

3. For this principle see Todd (1993) 123-5; Thür and Taeuber (1994) 202, 204, 221, 235-7; Bousquet and Gauthier (1993) 20-3; Chaniotis (1996a) 140, 145f; Harter-Uibopuu (1998) 148-51.

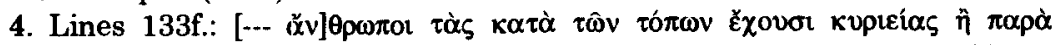

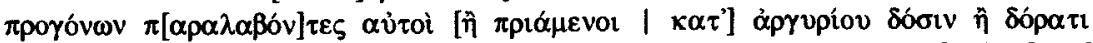

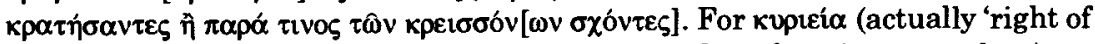
disposal': Wolff (1971) 337f.) with regard to ownership of territory see also Ager (1996) no. 146 (= I.Pergamon 245) line 129; Ager no. $171 \mathrm{I}$ (= I.Priene 111) line 11. For copleía in the context of private ownership see $S E G$ 31:1580, line 18; SEG 33:1041, line 6 (with the commentary of Wörrle (1988) 156, n. 28); SEG 35: 748, line 14 . 
5. Tod (1913); Raeder (1912); Piccirilli (1973); Ager (1996) (on which see Gauthier (1998)); Magnetto (1997); Harter-Uibopuu (1998).

6. Sheets (1994) 51-60 presents a representative selection of quotations from prominent scholars who have dismissed the importance of international law in ancient Greece.

7. The term is still used by Philipson (1911), but avoided by Martin (1940). See now Capdeville (1997) and Sheets (1994). G.C. Ténékides, Les relations internationales dans la Grèce antique (Athens 1993) was not available to me.

8. For studies of specific subjects see e.g. Gauthier (1972); Bravo (1980); Daverio Rocchi (1988); Canfora et al. (1990); Tausend (1992); Baltrusch (1994); Jehne (1994); Rousset (1994); Chaniotis (1996a). The subject of neutrality is the subject of studies by Alonso Troncoso (1987) and Bauslaugh (1990).

9. Ostwald (1982) 3.

10. Sheets (1994) 52.

11. Kränzlein (1963). Cf. Pringsheim (1950) 9-13.

12. E.g. Ager (1996) no. 3, lines 10-11 (= IG XII 3, 1259; Magnetto (1997) no. 1); Ager (1996) no. 20, line 4 (= SEG 42.479; Magnetto (1997) no. 68), Ager (1996) nos. 30-31, lines 8f, 18f. (= F.Delphes III 4.4, 351; Magnetto (1997) nos. 29-30); Ager (1996) no. 33, lines 6f. (= IG IX $1^{2} 3$ A; Magnetto (1997) no. 27); Ager (1996) 38 II (= IG IV $1^{2}$ 71; Magnetto (1997) no. 36); Ager (1996) no. 108 (= Milet I 3, 150) lines 79-83; Ager (1996) 118 (= IG IX 1, 689), lines 18-19; Ager (1996) no. 126 I (=F.Delphes III 2, 136) lines 19-30; Ager (1996) no. 128 II (= I.Cret. IV 181; Chaniotis (1996a) no. 44 Test. B). Cf. Kränzlein (1963) 20-1.

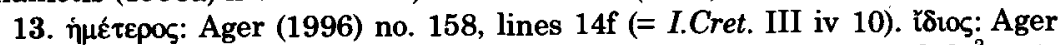
(1996) no. $74 \mathrm{I}$, line 117 (= I.Priene 37); Ager (1996) no. 139, line 8 (= Syll. $\left.{ }^{3} 668\right)$; SEG 35.823, lines 23-4. oikeîos: Th. 4.98.3; Arist. Rhet. 1361a16-19. Cf. n. 20.

14. Robert and Robert (1989) 73f. Cf. n. 23.

15. Kränzlein (1963) 13-16; Chaniotis (1996a) 93, n. 551. ě́ $\chi \omega:$ e.g. I.Cret. III vi 7 = Chaniotis (1996a): no. 64 lines 4f.; Ager (1996) no. 74 I (= I.Priene 37) lines

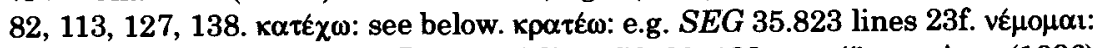

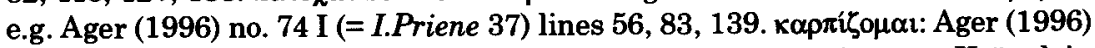

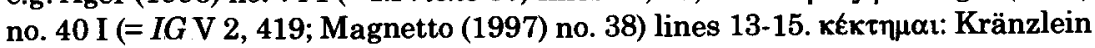
(1963) 19-20.

16. Ager (1996) no. 163 (= F.Delphes III 4.3, 280).

17. Ager (1996) no. $158 \mathrm{II}$, lines 68f. (= I.Cret. III iv 9).

18. Ager (1996) no. $74 \mathrm{I}$ (= I.Priene 37).

19. Cf. Isoc. On the Peace 17.

20. Ager (1996) no. 159 (I.Olympia 52).

21. In another arbitration between Sparta and the Achaean League (I.Olympia $47=$ Ager (1996) no. $137=$ Harter-Uibopuu (1998) no. 11) the restoration [ $\varepsilon i$

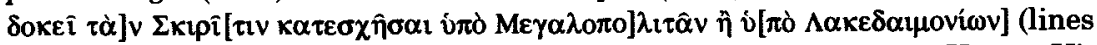

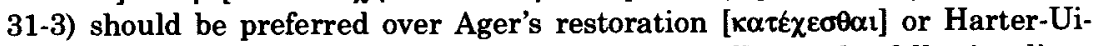
bopuu's к $\alpha \tau \chi \eta \hat{\eta} \sigma \theta \alpha$ ('daß die Skiritis gehalten wird'). As the following lines show, the judges had to answer the question who had occupied the land at the return of the Herakleidai (lines 35-7). For a similar case see Ager (1996) no. 158 I (= I.Cret. III iv 10) lines 21-2. For a neutral use of the verb katechein cf. also the senatus consultum, which concerns a later arbitration between Samos and Priene (before $135 \mathrm{BCE}$ ), I.Priene $40=$ Ager (1996) no. $160 \mathrm{I}$, line 7f. A similar 


\section{Justifying Territorial Claims in Classical and Hellenistic Greece}

use is attested also, for example, in a senatus consultum concerning a dispute between Magnesia on the Maiander and Priene (c. 175-160). This verb is used in the clause that establishes as the basis for the decision of the judges the possession of the disputed land at the moment when Magnesia and Priene became allies of the Romans (Ager (1996) no. $120 \mathrm{II}=$ I.Magnesia 93, lines 20-2).

22. Ager (1996) no. 171 I (= I.Priene 111).

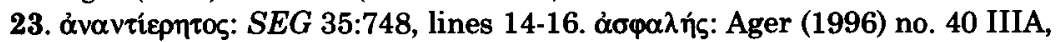
line 6; $B G U$ 419, line 18. Beßaiws et sim.: Dem. 12.21f.; SEG 47: 1745, line 20; Ager (1996) no. 138A, line 25 (= IG IV $1^{2} 76$ ); Harter-Uibopuu (1998) no. 12, line

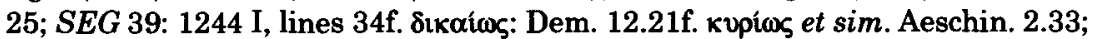
Syll. ${ }^{3} 279$ lines 18f.; Ager (1996) no. 158 I, line 28; SEG 38: 619, lines 23-7; cf.

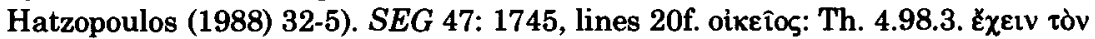

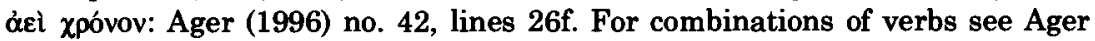
(1996) no. 26 I (= OGIS 13; RC 7) line 5; Ager (1996) no. 158 (= I.Cret. III iv 9)

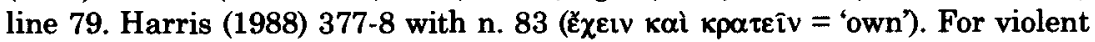
and unlawful occupation see Kränzlein (1963) 15-21; e.g. Arr. An. 1.27. 4 (Ager (1996) no. 6; Ager (1996) no. 74 I, line 100; Is. 10.1; 10.8. Cf. also the use of the verbs $\kappa \alpha \tau \alpha \lambda \alpha \mu \beta \alpha$ vetv and $\dot{z} \pi \beta \alpha i v \omega$ in Ager (1996) no. 74 I, lines 109f, 114, $116 f$. to express a violent or unlawful acquisition as opposed to the customary (I, line 106).

24. Ager (1996) no. 146, lines $142 \mathrm{f}$ (= I.Pergamon 245). The restoration is certain; cf. line 137.

25. Xen. Cyr. 7.5.73.

26. Ager (1996) no. 5 . I rely on the text in $S E G$ 46: 787, which is based on a recent edition and discussion by Hatzopoulos (1997). Cf. Hatzopoulos (1996) II no. 6. For further bibliography see $S E G$ 45: 790 and 47: 935 .

27. For the conditional and unconditional grant of land in Makedonia see Hatzopoulos (1988) 29-35 and (1996) I 434-9.

28. $S E G$ 39: 1426; Ager (1996) no. 42; Magnetto no. 40. Historical commentary: Jones and Habicht (1989). For the legal implications see Chaniotis (1993).

29. See most recently Harris (1995) 41-2, 57-62.

30. [Dem.] 12.21f. For the question of the letter's authenticity see FGrHist II C 108.

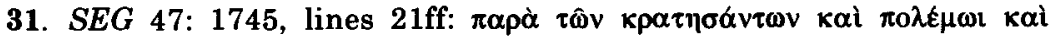
$\sigma[v v] \mid$ Ońkols.

32. For the legal basis of Athenian claims to Amphipolis see Jehne (1992).

33. Ager (1996) no. 26 I (= OGIS 13; RC 7) lines 11-13.

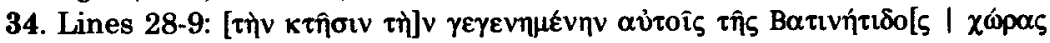

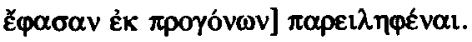

35. Ager (1996) no. 74 I (= I.Priene 37) line 117: ex arches. Ager no. 126 I (= F.Delphes III 2, 136) 33: ex arches. Cf. Ager (1996) no. 37 (= IPArk 25; Magnetto no. 35) line 6: ex archar (but this document is probably not an international arbitration). Cf. Ager (1996) no. 129 A (= F.Delphes III 4.4, 354) col. I, lines $20 f$. (re-establishment of boundary stones set $e x$ arches).

36. See $n .81$ below. For this type of argument see also Harter-Uibopuu (1998) $153 f$.

37. Cf. Plu. Sulla 13. 
38. Partsch (1906); 16, 48; Marshall (1980) 648f.; Scuderi (1991) with further bibliography); Harter-Uibopuu (1998) 170.

39. Isoc. Paneg. 177.

40. Ager (1996) no. 120 II (= I.Magnesia 93), lines 20-2. Marshall (1980) 648.

41. Ager (1996) no. 156 (= IG IX 2, 89). For the meaning of chorion eremon see now Baker (2000).

42. Ager (1996) 428f.

43. In the conflict of Hierapytna and Itanos (140 and $112 \mathrm{BCE}$ ) it was the arrival of Roman envoys in $140 \mathrm{BCE}$. For the senatus consultum of 140 BCE see Ager (1996) no. 158 I, lines 21f. (= I.Cret. III iv 10); for the senatus consultum of 112 BCE see Ager no. 158 I, lines 56-9 and 64-7 (= I.Cret. III iv 10); Ager (1996) no. 158 II, lines 51-4 (= I. Cret. III iv 9 . In the conflict of Sparta and Messene (138 BCE) it was the arrival of L. Mummius in Greece during 146 BCE; see Ager no. 159, lines 52-5 (=I.Olympia 52).

44. Ager (1996) no. 160, line 8 (= I.Priene 40).

45. Testimony of witnesses: Ager (1996) no. 70 (= IG IX 2, 521) (conflict between Kondaia and another city, possibly Gonnoi, second century). Ager (1996) no. 54 II B, lines 10-23 (conflict between Gonnoi and Herakleia, late third century).

46. This is how one should understand the phrase echein kai nemein in Ager (1996) no. 26 I, line 5 (= OGIS 13; RC 7), cf. lines 16-20. See also Ager (1996) 158 II (= I.Cret. III iv 9 ) lines $38 \mathrm{f}$. The actual exercise of property rights was also relevant in the conclusion of treaties of alliance: an ally sometimes obliged himself to defend the territory which his partner owned and controlled when the treaty was concluded (i.e. not territory occupied later or territory lost and reclaimed): Chaniotis (1996a) 92-3. E.g. I.Cret. III iii $4=$ Chaniotis (1996a) no. 28, lines 11f.

47. Dem. 12.23; I.Priene $37=$ Ager no. 74 I, lines 83-90 and 127-31; I.Cret. III iv $10=$ Ager (1996) no. $158 \mathrm{I}$, lines 40-2 (for this passage see Chaniotis (1996a) 337). This argument is also known from Greek law of property: see, e.g., Isaeus 8.44.

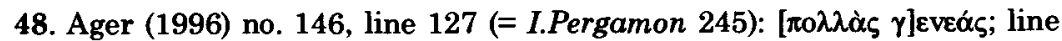

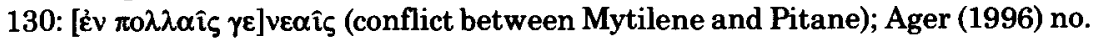

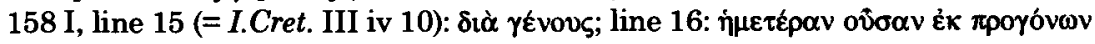
(conflict between Hierapytna and Itanos).

49. Ager (1996) no. 26 I, lines 4-6 (= OGIS 13; RC 7).

50. Chaniotis (1996a) 169-72.

51. Arist. Pol. 1256b23. Cf. Kränzlein (1963) 108. For the right of conquest in general, see Bickermann and Sykutris (1928) 26-9 and Bickermann (1932) 50-3.

52. Th. 4.98.2-3.

53. E.g. Plb.18.50.4; 28.1.4. For examples see also Bickermann (1932) 50-3, Chaniotis (2004).

54. Ager (1996) 146, lines 130-50 (= I.Pergamon 245); Boffo (2001) 239f.

55. Cf. Ager (1996) 404. Seleukos' victory at Kouropedion and the proprietary rights on the territory of Lysimachos resulting from it played an important role on the eve of the war between Antiochos III and Rome; see Bickermann (1932). 


\section{Justifying Territorial Claims in Classical and Hellenistic Greece}

56. Jonnes and Ricl (1997) (= SEG 47: 1745). Cf. the commentary of Ph. Gauthier in Bull. Epigr. 1999 no. 509.

57. Kränzlein (1963) 108-13. Cf. Brulé (1978) 138-42; Bravo (1980).

58. For this idea in the Greek dedicatory practices see Grotanelli (1991).

59. Syll. ${ }^{3} 10 ;$; GHI 16; SEG 46: 1173. Cf. Hdt. 3.47 and Chaniotis (1988) $308 f$.

60. Ager (1996) no. 74 (= I.Priene 37).

61. For battle as a 'verdict, judgment' (krisis) cf. Plb. 13.3.4.

62. Isoc. Panathenaicus 177.

63. Isoc. Archidamus 24 and 32; Panegyricus 177; Panathenaicus 254.

64. Kränzlein (1963) $108 f$.

65. Bickermann and Sykutris (1928) 27f.: 'Ein Gewaltakt kann aber das Recht nicht begründen, die Eroberung an sich würde also nicht als Rechtstitel aufgefaßt, wenn sie nicht als Vergeltung, als eine Represaille erschien.'

66. Karavites (1982) 99-106; Babrius Fable 89 is an ironic comment on this practice.

67. Dem. 18.181. For $\pi \alpha \rho \alpha \varphi €$ î $\sigma \theta \alpha$ in the sense of unlawful deprivation of property in international law, cf. Ager (1996) no. 74 I, lines 91, 93, 118 (=I.Priene $37)$.

68. I.Oropos 745a lines. 25-8: adikoumenos kai ou adikon proteros.

69. Ager (1996) no. 158 I (= I.Cret. III iv 10) 6-8.

70. Aeschin. 2.33.

71. For the events see Piccirilli (1973) 217-20 no. 58.

72. Antiphanes fr. 167 (Kassel-Austin) (= Plu. Demosthenes 9).

73. Isoc. Archidamus 19; Antipatros FGrHist $69 \mathrm{~F} 1$.

74. Cf. also Ager (1996) no. 88, lines 42-5 (= SEG 27: 123).

75. A conflict between Mytilene and Pitane may present another similar case. Pitane had bought a disputed territory from Antiochos I, who had inherited it from Seleukos I; the latter had occupied it after his victory over Lysimachos (see p. 196). If the Mytileneans could still claim the land as their own, it was possibly because Seleukos had not conquered it from them, but from Lysimachos.

76. E.g. in the conflict between Narthakion and Melitaia. See Ager (1996) no. 156 (= IG IX 2, 89), lines 23f: adikos. Cf. Ager (1996) (= OGIS 13; RC 7): [meta b]ias.

77. Kränzlein (1963) 94-103; cf. Partsch (1906) 23. For references to ancestral ownership in legal conflicts between private individuals, see, e.g., SEG 31:1580, line 16: progoniken; line 18: progonon (Ephesos? undated).

78. Plu. Mor. $230 \mathrm{~cd}=$ Piccirilli (1973) $124 \mathrm{f}$. no. 26 . For a possible reference to graves in the context of international arbitration see Ager (1996) no. 62, lines 8f. The restoration in this text is not certain: see $S E G$ 45: 588 .

79. Plu. Solon 10. For the importance of the cult of ancestors see Antonaccio (1995) 261-8; Malkin (1993).

80. See p. 199. The Romans had a different view; see Bickermann (1932) $51 f$.

81. Antipatros FGrHist 69 F 1.

82. Dem. 12.21: ex arches; Aeschin. 2.31: ex arches.

83. Chaniotis (1988) 114. A few examples: Ager (1996) nos. 50, 74 I, 146, 158 II.

84. Ager (1996) no. $74 \mathrm{I}$, lines 118-23 (= I.Priene 37). For the historical works cited in this conflict see Curty (1989). 


\section{The Law and the Courts in Ancient Greece}

85. For examples see Fischer (1937) 65-74; Nilsson (1951) 49-80. Some recent treatments of the use of myths in interstate relations (but not in territorial conflicts): Scheer (1993); Curty (1995); Jones (1999).

86. Ager (1996) no. $158 \mathrm{I}$, lines 27f. (= I.Cret. III iv 10).

87. Ager (1996) no. 158 II, lines 54-7 (= I.Cret. III iv 9).

88. Plb. 22.8.10; cf. Walbank (1979) 190; Allen (1983) $74 f$.

89. Plb. 31.7.6. Holleaux (1938) 418-25.

90. Cf. the principles applied in the transactions between private persons as described by Theophrastus in his treatise On Sale (fr. 21 Szegedy-Maszak); cf. Pringsheim (1950) 134-41; Todd (1993) 237-41. The same principle applies to wills. See e.g. Isaeus 10.2 (I owe this reference to Lene Rubinstein).

91. Ager (1996) no. 163 I (= F.Delphes III 4.3, 280). See also above, p. 188.

92. Xen. Hell. 3.2.31. Cf. Staatsverträge 217 and the commentary of Gschnitzer (1958) 12.

93. Th. 1.25f. See Gschnitzer (1958) 134 and n. 18; Graham (1983) $150 f$.

94. Ager (1996) no. 42, lines 29f.: 'The Council and the Assembly have resolved to give (dounai) the public land to them'; lines 41f.: dotheises.

95. Th. 1.25f. See Gschnitzer (1958) 134 and n. 18; Graham (1983) 150 f.

96. Plb. 22.5.4; cf. 25.4.5. See also e.g. Plb. 18.47 .10 and 12. See now Gabrielsen (1997) 47-53 and Bresson (1999) 106-18 with further bibliography.

97. See Dareste, Haussoullier, and Reinach (1894-1904) II 132-45; Bertrand (1987) 95-8.

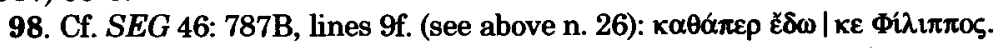

99. I.Cret. III vi 7; Staatsverträge 553. Latest edition and commentary: Chaniotis (1996a) 383-93 no. 64. Cf. the important contributions of Gschnitzer (1958) 35-8 and (1975). See also Perlman (1996) 233f. and 257f. Here, I summarise the views expressed in Chaniotis (1996a) 387-90.

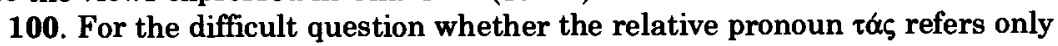
to the islands, or to the land and the city as well, see the discussion in Chaniotis (1996a) 388. This is an excellent example of the use of $\check{\chi} \chi \omega$ to express possession, but not ownership.

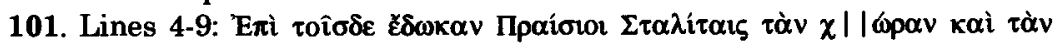

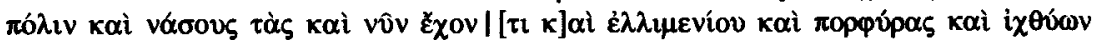

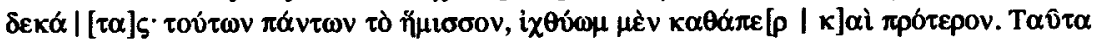

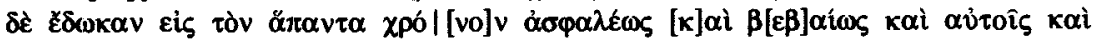
Ėкүóvorc.

102. For further parallels see Chaniotis (1996a) $389 \mathrm{nn}$. 1832-3.

103. The mythological precedents (e.g. Antipatros FGrHist $69 \mathrm{~F} 1$ ) should best be left aside.

104. E.g. Ager (1996) no. 71 I (= SEG 29: 1130 bis) lines 5f.; Ager (1996) no. 120 II (= I.Magnesia 93) line 27; Ager (1996) no. 124 (=SEG 33: 861) line 9; Ager no. 129 (= F.Delphes III 4.1, 362) line 28; line 43; Ager no. 146 (= I.Pergamon 245) line 147; Ager no. 158 II (=I.Cret. III iv 9) line 30f.; Ager no. 164 I (=I.Cret. I xvi 3) line 12. Cf. the praise of judges and advocates: Ager (1996) no. $85(=S E G$ 13: 327) line 29; Ager (1996) no. 171 I (= I.Priene 111) line 149; Ager (1996) no. $171 \mathrm{II}$ (= I.Priene 120) line 25.

105. This point is made by Sheets (1994) 58f. in connection with the trial at 


\section{Justifying Territorial Claims in Classical and Hellenistic Greece}

Plataia. Examples from territorial conflicts: Chaniotis (1996a) 318-37. Cf. also p. 193.

106. See nn. 35, 47, 77, 90.

107. Karavites (1982) esp. 91-132; Ducrey (1999) xix-xx, 289-311 with further bibliography.

108. Staatsverträge II 102. On the Lelantine war and the historicity of this agreement see most recently Parker (1997) 99-105.

109. Aeschin. $2.115=$ Staatsverträge 104. See Lefèvre (1998) 147-51 for the oath and the question of its historicity.

110. Collections of testimonia for the koinoi nomoi or koina nomima: Triantaphyllopoulos (1985) 110; Ducrey (1999) 289-95; Capdeville (1997) 276 n. 16. On their importance for Greek international law: Sheets (1994).

111. See Weinfeld (1990) for the influence of diplomatic contacts for the development of common covenantal traditions in Greece and the Near East; $c f$. Chaniotis (1999) for the role played by the exchange of written documents in the standardisation of a legal vocabulary.

112. For conditional self-curses in oath ceremonies in court and their importance as a form of social control see Faraone (1999).

113. Diagoras of Melos is said to have lost his belief in divine powers when observing how many evil men went unpunished - see Guthrie (1971) 236. In his Fables (2), Babrius narrates the witty fable of a peasant who yielded to despair when he realised that the gods failed to punish even men who had stolen sacred property.

114. For Critias' scepticism about divine justice see Guthrie (1971) 243-4. Cf. Plb. 6.56.9-12.

115. On this subject see Chaniotis (2003). 